\title{
Effects of rumen undegradable protein supplementation on productive performance and indicators of protein and energy metabolism in Holstein fresh cows
}

\author{
H. Amanlou, T. Amirabadi Farahani, ${ }^{1}$ and N. Eslamian Farsuni \\ Department of Animal Science, University of Zanjan, Zanjan 45371-38791, Iran
}

\begin{abstract}
The objective of this study was to determine the effects of feeding increased dietary crude protein $(\mathrm{CP})$ on productive performance and indicators of protein and energy metabolism during $21 \mathrm{~d}$ postpartum. Thirty multiparous Holstein dairy cows were balanced by previous lactation milk yield, body condition score (BCS) at calving, and parity and randomly allocated to 1 of 3 dietary treatments from calving until $21 \mathrm{~d}$ postpartum. Dietary treatments were $16.0 \% \mathrm{CP}$ with $5.0 \%$ rumen undegradable protein (RUP) based on dry matter (DM) (16CP), $18.7 \%$ CP with $7.0 \%$ RUP based on DM (19CP), and $21.4 \% \mathrm{CP}$ with $9.0 \%$ RUP based on DM $(21 \mathrm{CP})$. Diets were similar in net energy for lactation (approximately $1.7 \mathrm{Mcal} / \mathrm{kg}$ of $\mathrm{DM}$ ) and $\mathrm{CP}$ levels were increased with corn gluten meal and fish meal. Dry matter intake (DMI) was increased by increasing dietary CP levels from 16.0 to $19.0 \%$ of DM, but dietary CP beyond $19.0 \%$ had no effect on DMI. Milk yields were 4.7 and $6.5 \mathrm{~kg} / \mathrm{d}$ greater in cows fed the $19 \mathrm{CP}$ and $21 \mathrm{CP}$ diets versus those fed the $16 \mathrm{CP}$ diet, whereas $4 \%$ fat-corrected milk was greater for cows fed the $21 \mathrm{CP}$ than the $16 \mathrm{CP}$ diet (36.0 vs. $31.4 \mathrm{~kg} / \mathrm{d}$ ). Milk protein content and yield, lactose yield, and milk urea nitrogen were elevated by increased dietary CP. Milk lactose content and fat yield were not different among dietary treatments, but milk fat content tended to decline with increasing content of $\mathrm{CP}$ in diets. High $\mathrm{CP}$ levels increased milk $\mathrm{N}$ secretion but decreased milk $\mathrm{N}$ efficiency. Apparent digestibility of DM, CP, and neutral detergent fiber was greater on the $19 \mathrm{CP}$ and $21 \mathrm{CP}$ diets compared with the $16 \mathrm{CP}$ diet. Cows fed the $19 \mathrm{CP}$ and $21 \mathrm{CP}$ diets lost less body condition relative to those fed the $16 \mathrm{CP}$ diet over $21 \mathrm{~d}$ postpartum. Feeding higher CP levels increased the concentrations of serum albumin, albumin to globulin ratio, and urea nitrogen and decreased aspartate aminotransferase,
\end{abstract}

Received July 28, 2016.

Accepted January 10, 2017.

${ }^{1}$ Corresponding author: T.Farahani@znu.ac.ir nonesterified fatty acids, and $\beta$-hydroxybutyrate, but had no effect on globulin, glucose, cholesterol, or triacylglycerol. These findings indicated that elevating dietary CP up to $19.0 \%$ of DM using RUP supplements improved DMI, productive performance and the indicators of protein and energy metabolism from calving to 21 d postpartum.

Key words: dietary protein, performance, dry matter intake, fresh cow

\section{INTRODUCTION}

Following calving, cows experience negative nutrient balances, especially energy and protein, because nutrient intake is less than required to support lactation. Feeding high-grain diets is one approach used to reduce negative energy balance (NEB). However, because of greater propionate production, high grain diets might decrease DMI and increase the risk of metabolic disorders (Allen and Piantoni, 2013). Likewise, abomasal glucose infusion for reducing NEB failed to show benefits on DMI and milk yield immediately after calving (Ørskov et al., 1977; Larsen and Kristensen, 2009; Carra et al., 2013). Compared with NEB, negative MP balance has received less research attention (Grummer, 1995; Bell et al., 2000). Cows with protein deficiency will mobilize skeletal muscles and other protein sources. The mobilized protein reserves ranged from 8 to $21 \mathrm{~kg}$ during the first 5 to $6 \mathrm{wk}$ postpartum (Komaragiri et al., 1998; Chibisa et al., 2008). During this time, protein mobilization is essential to supply AA and glucose for the mammary gland, but excessive mobilization results in increased incidence of metabolic disorders, immune dysfunction, and poor reproductive and lactation performance (Ji and Dann, 2013). Some previous reports (Cunningham et al., 1996; Broderick, 2003; Socha et al., 2005) indicated that increasing CP above $16.7 \%$ in dairy cows rations had no effect on milk production or milk components, but other studies (Broderick et al., 2002; Flis and Wattiaux, 2005) reported positive milk production responses when dietary CP levels increased with RUP supplements. In addition, Law et al. (2009) 
reported that increasing dietary $\mathrm{CP}$ levels from calving day to d 150 increased DMI and milk production and reduced BHB concentrations but had no effect on nonesterified fatty acids (NEFA) concentrations.

Most of these studies have been conducted on early(>21d) or mid-lactation dairy cows (Wright et al., 1998; Broderick et al., 2008; Lee et al., 2015) and only a few studies (Brown and Allen, 2013; Larsen et al., 2014) have focused on increased protein supply in fresh cows. Larsen et al. (2014) investigated the effects of abomasal casein infusion on the performance of transition cows from calving until d 29 of lactation. They found that additional MP supply after calving can considerably increase milk production and improve plasma protein concentrations and immune status in dairy cows. Larsen et al. (2014) found that MP supply played a more important role than energy supply in postpartum cows.

In a recent meta-analysis of the effect of casein infusion on DMI responses on cows fed for ad libitum intake, Martineau et al. (2016) recognized that there was an interaction between MP balance values and casein infusion. They indicated that casein infusion increased DMI in cows with negative MP balance but had a negative effect on DMI when cows were in positive MP balance. This may be due to increased oxidation of AA in excess of requirements, increasing hepatic oxidation of acetyl-CoA and contributing to satiety (Martineau et al., 2016). Therefore, it was hypothesized that additional MP supply using RUP supplements in fresh cows can increase DMI for several weeks following parturition when cows are in negative protein balance. The objective of our study was to evaluate the effects of increased dietary CP levels on DMI, milk production, blood metabolites, nutrient digestibility, and nitrogen utilization in fresh cows.

\section{MATERIALS AND METHODS}

\section{Cows and Experimental Design}

The experiment was conducted on a commercial dairy herd in Iran from September to November 2010. Thirty multiparous Holstein dairy cows (mean parity \pm $\mathrm{SD} ; 3.3 \pm 0.5$ ) were used in a completely randomized design with 3 dietary treatments from calving until 21 $\mathrm{d}$ of lactation. Cows were assigned in a balanced manner to treatments based on previous milk yield, BCS at calving, and parity. During the close-up period, $21 \pm 3$ $\mathrm{d}$ before calving, cows were housed in a freestall barn and fed the same close-up diet $\left(\mathrm{NE}_{\mathrm{L}}=1.6 \mathrm{Mcal} / \mathrm{kg}, \mathrm{CP}\right.$ $=13.0 \%$, DM basis) for ad libitum intake twice daily at 0800 and $1700 \mathrm{~h}$. As cows showed primary signs of calving, cows were moved to maternity pens, and calf weight and first-milking colostrum yield were recorded immediately postpartum by calving personnel. After calving, cows were assigned to their experimental diets and moved to individual stalls where they were housed until $21 \mathrm{~d}$ after calving, with free access to water. Before treatment application, cows suffering retained placenta, milk fever, mastitis, pneumonia, laminitis, dystocia, and rectal temperature $\left(\geq 39.4^{\circ} \mathrm{C}\right)$ were not entered in the experiment.

Chemical composition of individual feed ingredients are listed in Table 1. The diet fed to close-up cows and experimental diets (Table 2) were formulated according to the NRC (2001) model. The concentrate to forage ratio (DM basis) was 55:45 for all dietary treatments. Dietary CP was increased from 16.0 to $21.0 \%$ by replacing cereal grain (barley and corn) with fish meal (FM) and corn gluten meal (CGM). Resulting dietary treatments were $16.0 \% \mathrm{CP}$ with $5.0 \%$ RUP (16CP), $18.7 \%$ CP with $7.0 \%$ RUP (19CP), and $21.4 \%$ CP with $9.0 \%$ RUP (21CP). Protein supplies and AA balances were estimated by actual individual cow DMI, BW, BCS, milk yield, and milk composition using NRC (2001) and CNCPS v. 6.5 (Cornell University, Ithaca, NY), respectively.

\section{Sampling and Data Collection}

Dietary treatments were fed as TMR 3 times daily at 0800,1600 , and $2200 \mathrm{~h}$ for $10 \%$ orts, and orts were collected and recorded daily. Samples of TMR and orts were taken twice a week, dried at $60^{\circ} \mathrm{C}$ for $48 \mathrm{~h}$, and then composited by week and treatment. Individual feed ingredients were also sampled weekly and frozen at $-20^{\circ} \mathrm{C}$ for chemical composition analysis. Feed samples were ground through a 1-mm screen and analyzed in 3 replications for DM (AOAC, 1990; method 930.15), CP using the Kjeldahl method (AOAC, 1990; method 984.13), ether extract using Soxhlet extraction method with diethyl ether (AOAC, 1990; method 920.39), ash (ignition at $600^{\circ} \mathrm{C}$ for $2 \mathrm{~h}$; AOAC, 1990, method 942.05), ADF using cetyl trimethyl ammonium bromide (CTAB) and $1 \mathrm{~N} \mathrm{H}_{2} \mathrm{SO}_{4}$ (AOAC, 1990; method 973.18), and NDF using sodium sulfite and heat-stable

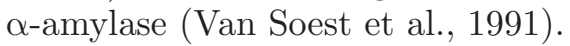

The cows were milked 3 times daily at 0700, 1500, and $2100 \mathrm{~h}$, and milk yields were recorded at each milking. Milk samples were taken weekly from 3 consecutive milkings and composited in proportion to milk yield. Milk samples were analyzed for fat, protein, lactose, and urea by mid-infrared spectroscopic procedure using a Milkoscan (CombiFoss 78110; Foss Analytical A/S, Hillerød, Denmark). Feed efficiency was calculated by dividing $4 \%$ FCM by DMI. 
Table 1. Chemical composition of feed ingredients based on DM (\%)

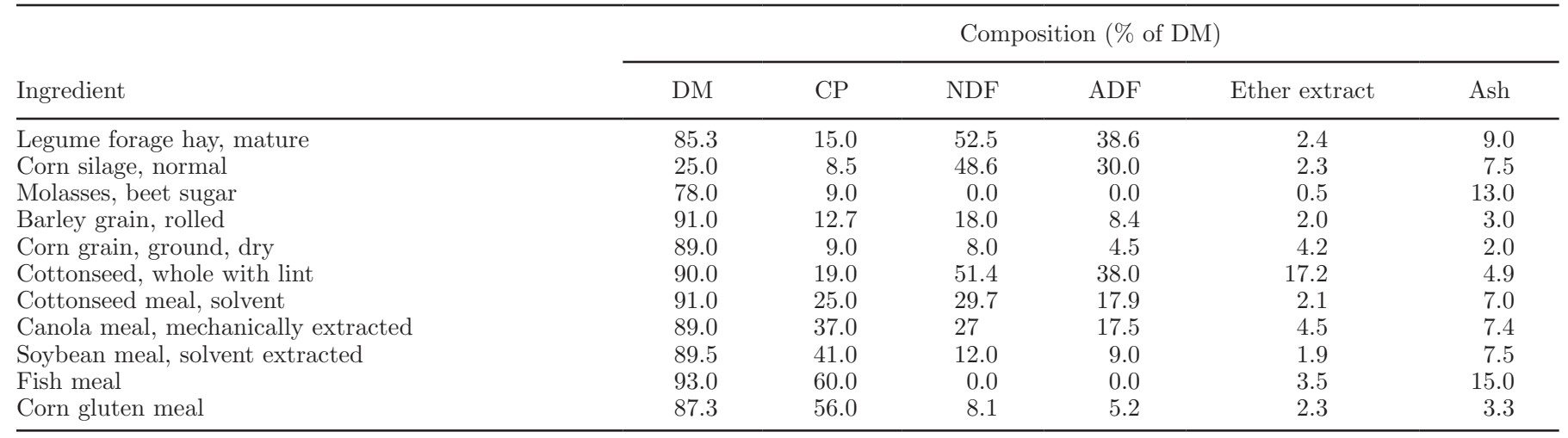

Cows were weighed weekly before the morning feeding, and weekly weights were used to calculate $\mathrm{NE}_{\mathrm{L}}$ and MP balance using the NRC (2001) model. Furthermore, $\mathrm{BW}$ at the beginning (calving day) and end of experiment (21 DIM) were used to calculate BW changes. Cows were scored (Edmonson et al., 1989; scale: 1 to 5) for body condition by 2 trained investigators at calving and at 21 DIM.

Blood samples were taken $4 \mathrm{~h}$ after morning feeding from the coccygeal vein using an evacuated tube without anticoagulant on d $0,3,7,14$, and 21 relative to parturition. Serum samples were collected fol-

Table 2. Feed ingredient composition of diets based on DM (\%)

\begin{tabular}{|c|c|c|c|c|}
\hline \multirow[b]{2}{*}{ Item } & \multirow[b]{2}{*}{ Close-up } & \multicolumn{3}{|c|}{ Diet $^{1}$} \\
\hline & & $16 \mathrm{CP}$ & $19 \mathrm{CP}$ & $21 \mathrm{CP}$ \\
\hline Legume forage hay, mature & 27.1 & 25.0 & 25.0 & 25.0 \\
\hline Corn silage, normal & 35.1 & 20.0 & 20.0 & 20.0 \\
\hline Molasses, beet sugar & 0.0 & 1.26 & 1.26 & 1.26 \\
\hline Barley grain, rolled & 12.5 & 16.26 & 13.68 & 11.09 \\
\hline Corn grain, ground, dry & 12.0 & 11.5 & 9.94 & 8.38 \\
\hline Cottonseed, whole with lint & 3.00 & 6.42 & 5.54 & 4.67 \\
\hline Cottonseed meal, solvent extracted & 0.0 & 3.27 & 2.83 & 2.39 \\
\hline Canola meal, mechanically extracted & 1.60 & 1.61 & 1.39 & 1.17 \\
\hline Soybean meal, solvent extracted & 5.00 & 6.87 & 5.95 & 5.01 \\
\hline Fish meal & 0.0 & 1.19 & 4.75 & 8.33 \\
\hline Corn gluten meal & 0.0 & 1.82 & 5.08 & 8.33 \\
\hline Fat powder ${ }^{2}$ & 0.0 & 1.59 & 1.37 & 1.16 \\
\hline Salt & 0.0 & 0.43 & 0.43 & 0.43 \\
\hline Calcium carbonate & 1.30 & 0.0 & 0.0 & 0.0 \\
\hline $\mathrm{NaHCO}_{3}$ & 0.0 & 1.51 & 1.51 & 1.51 \\
\hline Magnesium oxide & 0.10 & 0.16 & 0.16 & 0.16 \\
\hline Magnesium sulfate & 1.00 & 0.0 & 0.0 & 0.0 \\
\hline Calcium chloride & 0.60 & 0.0 & 0.0 & 0.0 \\
\hline Mineral premix ${ }^{3}$ & 0.0 & 0.45 & 0.45 & 0.45 \\
\hline Vitamin premix ${ }^{4}$ & 0.70 & 0.45 & 0.45 & 0.45 \\
\hline Toxin absorbent $^{5}$ & 0.0 & 0.15 & 0.15 & 0.15 \\
\hline Organic trace mineral $^{6}$ & 0.0 & 0.06 & 0.06 & 0.06 \\
\hline
\end{tabular}

${ }^{1}$ Diets designated as $16 \mathrm{CP}, 19 \mathrm{CP}$, and $21 \mathrm{CP}$ contained $16.0,18.7$, and $21.4 \% \mathrm{CP}$, respectively.

${ }^{2}$ Behparvaran Co. (Esfahan, Iran). Composition: $\mathrm{NE}_{\mathrm{L}}, 5.2 \mathrm{Mcal} / \mathrm{kg}$; moisture $2 \%$, calcium $9 \%$, crude fat $85 \%$ $(\mathrm{C} 16: 0,30 \mathrm{~g} / 100 \mathrm{~g}$ of fatty acids; C18:0, $20 \mathrm{~g} / 100 \mathrm{~g}$ of fatty acids; C18:1, $40 \mathrm{~g} / 100 \mathrm{~g}$ of fatty acids; C18:2, 9 $\mathrm{g} / 100 \mathrm{~g}$ of fatty acids; C18:3, $<1 \mathrm{~g} / 100 \mathrm{~g}$ of fatty acids).

${ }^{3}$ Premix contained per kilogram: $170 \mathrm{~g}$ of $\mathrm{Ca}, 100 \mathrm{~g}$ of $\mathrm{Mg}, 13 \mathrm{~g}$ of $\mathrm{Mn}, 20 \mathrm{~g}$ of Zn, $5 \mathrm{~g}$ of $\mathrm{Cu}, 0.2 \mathrm{~g}$ of I, $0.1 \mathrm{~g}$ of Se, $0.08 \mathrm{~g}$ of $\mathrm{Co}$, and $4 \mathrm{~g}$ of $\mathrm{Fe}$.

${ }^{4}$ Premix contained per kilogram for close-up: 8,000 IU of vitamin A, 2,500 IU of vitamin $\mathrm{D}_{3}$, and $100 \mathrm{IU}$ of vitamin E; and for postpartum: 1,800,000 IU of vitamin A, 400,000 IU of vitamin D, 8,000 IU of vitamin $\mathrm{E}$ and $3,000 \mathrm{mg}$ of antioxidant.

${ }^{5}$ Contained 0.04\% T-Toxin binder and 0.11\% Mycosorb based on DM (Alltech Inc., Nicholasville, KY).

${ }^{6}$ Availa-4 containing a combination of organic $\mathrm{Zn}, \mathrm{Cu}, \mathrm{Mn}$, and Co (Zinpro Corp., Eden Prairie, MN). 
lowing centrifugation at $2,500 \times g$ for $10 \mathrm{~min}$ and stored at $-20^{\circ} \mathrm{C}$ for later analysis. Serum samples were analyzed for concentrations of albumin (bromocresol green method at acidic pH, kit no. 1500001; Johnson et al., 1999), total protein (TP, biuret method, kit no. 1500028; Thomas, 1998), urea nitrogen (Berthelot method, kit no. 1400030; Thomas, 1998), aspartate aminotransferase (AST, International Federation of Clinical Chemistry method, kit no. 1400018; Bergmeyer et al., 1986), cholesterol (cholesterol oxidase-phenol 4-aminoantipyrine peroxidase method, kit no. 1500010; Deeg and Ziegenhorn, 1983), and triacylglycerol (TAG, glycerol-3-phosphate oxidase-phenol 4 aminoantipyrine peroxidase method, kit no. 1500032; Cole et al., 1997) using commercial kits (Pars Azmoon Laboratory, Tehran, Iran). Light absorbance was measured using a spectrophotometer (UNICCO, 2100, Zistchemi Co., Tehran, Iran) for all of the serum metabolites. Serum concentrations of NEFA (colorimetric method, kit no. FA 115; DeVries et al., 1976), and BHB (enzymatic method, based on 3-hydroxybutyrate dehydrogenase, kit no. RB1007; McMurray et al., 1984) were also measured using commercial kits (Randox Laboratories Ltd., Crumlin, UK), using a serum spectrophotometer (UNICCO, 2100, Zistchemi Co.). Globulin concentration was obtained as the difference between TP and albumin. At the time of blood sampling, whole blood glucose was measured by glucometer (Glucotrend, Roche, Welwyn Garden City, UK).

Fecal samples were taken from the rectum (approximately $400 \mathrm{~g}$ ) of all cows for 3 consecutive days every $8 \mathrm{~h}$ (3 times/d at 0700, 1500, $2300 \mathrm{~h}$ ) from d 19 to 21 DIM, and dried at $65^{\circ} \mathrm{C}$ for $48 \mathrm{~h}$. Fecal samples were ground through a 1-mm screen, pooled by cow and sampling day, and analyzed for DM, CP, and NDF. To determine the apparent total-tract digestibility of nutrients, acid insoluble ash was considered as an internal digestibility marker (Van Keulen and Young, 1977).

Daily energy balance was calculated using the NRC (2001) model, and milk N efficiency was calculated by dividing milk $\mathrm{N}$ by $\mathrm{N}$ intake. Health events were recorded daily over the experiment.

\section{Statistical Analysis}

The data were analyzed using PROC MIXED of SAS (version 9.3; SAS Institute Inc., Cary, NC). Dry matter intake, milk yield, feed efficiency, blood metabolites, and milk composition data were analyzed as repeated measures with the most suitable structure based on the lowest Akaike information criterion, corrected Akaike information criterion, and Bayesian information criterion values for each analysis (Littell et al., 1998). Time
(DIM and week) was entered in the model as a repeated variable. The following model was used:

$$
\mathrm{Y}_{\mathrm{ijk}}=\mu+\mathrm{T}_{\mathrm{i}}+\text { Time }_{\mathrm{j}}+\left(\mathrm{T} \times \text { Time }_{\mathrm{ij}}+\mathrm{C}_{(\mathrm{i}) \mathrm{k}}+\mathrm{e}_{\mathrm{ijk}},\right.
$$

where $Y_{i j k}$ is the dependent variable, $\mu$ is the overall mean, $T_{i}$ is the fixed effect of treatment, Time ${ }_{j}$ is the fixed effect of sampling time, $(\mathrm{T} \times \mathrm{Time})_{\mathrm{ij}}$ is fixed interaction between treatment and sampling time, $\mathrm{C}_{(\mathrm{i}) \mathrm{k}}$ is random effect of cow nested within treatment, and $\mathrm{e}_{\mathrm{ijk}}$ is the error term. The SLICE option of the LSMEANS statement from the MIXED procedure of SAS was used to determine difference among dietary treatments at every time point. Previous lactation yield, BCS and BW at calving, and the concentrations of serum metabolites obtained at calving day were used as the covariates and they were removed from model if $P>$ 0.2 . Body condition score, BW, and their changes were analyzed with the same model without sampling time and treatment $\times$ sampling time. Data are reported as LSM and statistical significances were declared at $P \leq$ 0.05 and $0.05<P \leq 0.10$ as trends toward significance using the Tukey's multiple comparison test.

\section{RESULTS AND DISCUSSION}

Cows assigned to dietary treatments did not differ in BW (mean \pm SE; $749 \pm 10.3 \mathrm{~kg})$, BCS $(3.25 \pm 0.06)$, calf BW (43.1 $\pm 0.53 \mathrm{~kg})$, close-up period length (21 $\pm 0.6 \mathrm{~d})$, parity $(3.3 \pm 0.09)$, previous lactation milk yield $(11,000 \pm 267 \mathrm{~kg})$, or first-milking colostrum yield $(5.9 \pm 0.4 \mathrm{~kg})$. In the present experiment, dietary treatments (Table 2) were formulated to contain $1.70 \mathrm{Mcal} /$ $\mathrm{kg}$ of $\mathrm{NE}_{\mathrm{L}}$ (DM basis; Table 3). The diets varied in NFC content from $41.0 \%$ for the 16CP diet to $37.5 \%$ for the $21 \mathrm{CP}$ diet because CGM and FM (as RUP sources) were substituted for barley and corn to reach increased amounts of dietary protein (Table 2). The estimated supplies of MP-bacterial as predicted by NRC (2001) were 883,957 , and $948 \mathrm{~g} / \mathrm{d}$ for the $16 \mathrm{CP}, 19 \mathrm{CP}$, and $21 \mathrm{CP}$ diets, respectively; and its supply increased $\sim 8 \%$ in the $19 \mathrm{CP}$ and $21 \mathrm{CP}$ diets relative to the $16 \mathrm{CP}$ diet (Table 3). However, the estimated supplies of MP-RUP were $617,1,005$, and $1,301 \mathrm{~g} / \mathrm{d}$ for the $16 \mathrm{CP}, 19 \mathrm{CP}$, and $21 \mathrm{CP}$ diets, respectively; and their supplies increased 63 and $110 \%$ in $19 \mathrm{CP}$ and $21 \mathrm{CP}$ relative to $16 \mathrm{CP}$ (Table 3).

According to CNCPS (version 6.5), the predicted supplies of Met, Lys, and Leu were 84,84 , and $76 \%$ of requirements, respectively, for cows fed 16CP; 92, 87, and $88 \%$, respectively, for cows fed $19 \mathrm{CP}$; and 95, 85, and $94 \%$, respectively, for cows fed $21 \mathrm{CP}$ (Table 3 ). The $19 \mathrm{CP}$ and $21 \mathrm{CP}$ diets met the His requirement, whereas the $16 \mathrm{CP}$ diet was $7 \%$ deficient in His. 
Table 3. Chemical composition of diets $(\mathrm{n}=3)$

\begin{tabular}{|c|c|c|c|c|}
\hline \multirow[b]{2}{*}{ Component } & \multirow[b]{2}{*}{ Close-up } & \multicolumn{3}{|c|}{$\operatorname{Diet}^{1}$} \\
\hline & & $16 \mathrm{CP}$ & $19 \mathrm{CP}$ & $21 \mathrm{CP}$ \\
\hline $\mathrm{DM}(\%)$ & 47.0 & 51.6 & 50.9 & 51.0 \\
\hline $\mathrm{NE}_{\mathrm{L}}{ }^{2}(\mathrm{Mcal} / \mathrm{kg}$ of $\mathrm{DM})$ & 1.6 & 1.7 & 1.7 & 1.7 \\
\hline $\mathrm{CP}(\%$ of $\mathrm{DM})$ & 13.0 & 16.0 & 18.7 & 21.4 \\
\hline $\mathrm{RDP}^{2}(\%$ of $\mathrm{DM})$ & 9.6 & 11.0 & 11.7 & 12.4 \\
\hline $\mathrm{RUP}^{2}$ (\% of DM) & 3.4 & 5.0 & 7.0 & 9.0 \\
\hline $\mathrm{NDF}(\%$ of DM) & 35.9 & 32.0 & 31.0 & 30.0 \\
\hline $\mathrm{ADF}(\%$ of $\mathrm{DM})$ & 23.9 & 21.5 & 20.9 & 20.3 \\
\hline NFC ( $\%$ of DM) & 41.4 & 41.0 & 39.3 & 37.5 \\
\hline Ether extract (\% of DM) & 3.1 & 4.7 & 4.6 & 4.5 \\
\hline Ash $(\%$ of DM) & 6.6 & 6.3 & 6.4 & 6.6 \\
\hline $\mathrm{DCAD}^{3}(\mathrm{mEq} / \mathrm{kg})$ & -48 & 351 & 327 & 304 \\
\hline \multicolumn{5}{|l|}{ Protein supply ${ }^{2}(\mathrm{~g} / \mathrm{d})$} \\
\hline RDP supply & 1,151 & 1,737 & 2,011 & 2,124 \\
\hline RDP balance & -56 & +114 & +252 & +381 \\
\hline RUP supply & 401 & 746 & 1,177 & 1,500 \\
\hline RUP balance & +169 & -532 & -303 & -157 \\
\hline MP supply & 989 & 1,574 & 2,042 & 2,328 \\
\hline MP-Bacterial & 626 & 883 & 957 & 948 \\
\hline MP-RUP & 307 & 617 & 1,005 & 1,301 \\
\hline MP-Endogenous & 56 & 73 & 80 & 80 \\
\hline MP balance & +129 & -440 & -258 & -127 \\
\hline \multicolumn{5}{|l|}{ AA balance $^{4}(\mathrm{~g} / \mathrm{d})$} \\
\hline Met requirements & 17 & 58 & 66 & 71 \\
\hline Met supply & 36 & 49 & 61 & 68 \\
\hline Met balance & +19 & -9 & -5 & -3 \\
\hline Lys requirements & 50 & 167 & 189 & 202 \\
\hline Lys supply & 106 & 141 & 165 & 172 \\
\hline Lys balance & +56 & -26 & -24 & -30 \\
\hline Leu requirements & 60 & 220 & 249 & 267 \\
\hline Leu supply & 114 & 168 & 220 & 253 \\
\hline Leu balance & +54 & -52 & -29 & -14 \\
\hline His requirements & 23 & 57 & 64 & 68 \\
\hline His supply & 37 & 53 & 64 & 68 \\
\hline His balance & +14 & -4 & 0 & 0 \\
\hline
\end{tabular}

\section{Health Disorders}

The incidence of postpartum disorders was recorded daily and reported as the number of incidents observed. The incidences of subclinical ketosis (BHB $\geq 1.2 \mathrm{mM}$ ) were 4 ( 1 on $\mathrm{d} 3$ and 3 cases on d 7 postpartum), 1 (on d 7 postpartum), and 2 (on d 7 postpartum) events for diets $16 \mathrm{CP}, 19 \mathrm{CP}$, and $21 \mathrm{CP}$, respectively. No clinical cases of ketosis, milk fever, or displaced abomasum were observed during the experiment. Lameness incidences were 1,2 , and 2 cases for $16 \mathrm{CP}, 19 \mathrm{CP}$, and $21 \mathrm{CP}$, respectively. Three cows were diagnosed with mastitis (2 and 1 cases for $16 \mathrm{CP}$ and $21 \mathrm{CP}$, respectively), and 8 cows experienced uterine disorders $(3$ each on diets $16 \mathrm{CP}$ and $19 \mathrm{CP}$ and 2 on the $21 \mathrm{CP}$ diet). Overall, 10 out of 30 cows in the 3 treatments were diagnosed with postpartum disorders $(\mathrm{n}=4,3$, and 3 cows in $16 \mathrm{CP}$,
$19 \mathrm{CP}$, and $21 \mathrm{CP}$ diets, respectively). These data should be interpreted with caution because of the small number of cows used in the present study.

\section{Dry Matter and Nutrient Intakes}

Increasing dietary CP using RUP supplements from 16.0 to $19.0 \%$ of $\mathrm{DM}$ increased intakes of $\mathrm{DM}, \mathrm{NE}_{\mathrm{L}}$, and CP $(P<0.01)$. However, dietary CP beyond $19.0 \%$ did not affect $\mathrm{DM}$ and $\mathrm{NE}_{\mathrm{L}}$ intakes (Table 4). Intakes of $\mathrm{NDF}$ and $\mathrm{ADF}$ were similar among different $\mathrm{CP}$ levels $(P>0.1$; Table 4$)$. We detected an effect of time $(P<$ $0.01)$ on all nutrient intakes but no time by treatment interaction $(P>0.05$; Table 4$)$ on intakes.

The increased DMI with the $19 \mathrm{CP}$ and $21 \mathrm{CP}$ diets compared with $16 \mathrm{CP}$, as observed in the present study, agrees with previous studies (Broderick and Reynal, 
2009; Cabrita et al., 2011; Giallongo et al., 2016) and a meta-analysis (Huhtanen and Hetta, 2012) that reported a positive relation between dietary protein levels and DMI. However, some studies observed no effect (Colmenero and Broderick, 2006; Larsen et al., 2014) or even reported a reduction in DMI by increasing CP supply (Kröber et al., 2000). These diverse results could be due to differences in sources and levels of protein, lactation stage of animals, and supplementation of protein in excess of cow requirements.

Feed intake is likely controlled predominantly by the hepatic oxidation of fuels (e.g., NEFA, propionate, glucogenic AA) during the transition period, so increased supply of propionate and NEFA to the liver likely decreases DMI due to increased oxidation of acetyl CoA (Allen et al., 2009). Therefore, decreased NEFA concentrations in cows fed high CP diets compared with cows fed the $16 \mathrm{CP}$ diet may have contributed to increased DMI. Additional AA supply could differently influence the mechanisms of feed intake control dependent on MP balance status (Martineau et al., 2016). In positive MP balance status, the oxidation of AA in tricarboxylic acid cycle is increased, elevating energy charge in liver, and inducing satiety (Oba and Allen, 2003). However, when glucose demand is increased immediately after calving, the importance of AA as gluconeogenic substrate is increased (Overton et al., 1999). These results are supported by Martineau et al. (2016), indicating a positive association between DMI and postruminal infusion of protein for cows in negative MP balance. Also, in the current study, increasing dietary CP levels by RUP supplements has likely increased duodenal EAA supply, especially His, resulting in increased DMI in high CP diets as shown by other research (Ouellet et al., 2014; Patton et al., 2015; Giallongo et al., 2016). Moreover, low CP diets with RDP deficiency decrease ruminal fibrolytic bacteria activities and the rate of NDF digestion, decreasing feed intake (Weigel et al., 1997; Allen, 2000; Owens et al., 2014). Thus, another factor that may have contributed to increased DMI with high CP diets in the current study is greater NDF digestibility (Table 5).

\section{Milk Production and Composition}

Increasing dietary CP levels using RUP supplements from 16.0 to $19.0 \%$ of DM increased milk yield $(P<$ $0.01)$. However, milk yield did not differ $(P>0.05)$

Table 4. Effects of increasing dietary CP and RUP supply on nutrient intake, milk yield, milk composition, energy balance, MP balance, feed efficiency, and milk nitrogen efficiency in fresh dairy cows

\begin{tabular}{|c|c|c|c|c|c|c|c|}
\hline \multirow[b]{2}{*}{ Item } & \multicolumn{3}{|c|}{ Diet $^{1}$} & \multirow[b]{2}{*}{ SEM } & \multicolumn{3}{|c|}{$P$-value } \\
\hline & $16 \mathrm{CP}$ & $19 \mathrm{CP}$ & $21 \mathrm{CP}$ & & Diet & Time & Diet $\times$ Time \\
\hline \multicolumn{8}{|l|}{ Intake } \\
\hline DM (kg/d) & $15.56^{\mathrm{b}}$ & $17.03^{\mathrm{a}}$ & $16.89^{\mathrm{a}}$ & 0.3 & $<0.01$ & $<0.01$ & 0.7 \\
\hline $\mathrm{NE}_{\mathrm{L}}(\mathrm{Mcal} / \mathrm{d})$ & $26.45^{\mathrm{b}}$ & $29.12^{\mathrm{a}}$ & $29.22^{\mathrm{a}}$ & 0.5 & $<0.01$ & $<0.01$ & 0.7 \\
\hline $\mathrm{CP}(\mathrm{kg} / \mathrm{d})$ & $2.48^{\mathrm{c}}$ & $3.18^{\mathrm{b}}$ & $3.61^{\mathrm{a}}$ & 0.06 & $<0.01$ & $<0.01$ & 0.5 \\
\hline $\operatorname{RDP}(\mathrm{kg} / \mathrm{d})$ & $1.71^{\mathrm{b}}$ & $1.99^{\mathrm{a}}$ & $2.09^{\mathrm{a}}$ & 0.03 & $<0.01$ & $<0.01$ & 0.7 \\
\hline $\operatorname{ADF}(\mathrm{kg} / \mathrm{d})$ & 3.34 & 3.55 & 3.42 & 0.06 & 0.11 & $<0.01$ & 0.7 \\
\hline Milk yield (kg/d) & $32.73^{\mathrm{b}}$ & $37.43^{\mathrm{a}}$ & $39.22^{\mathrm{a}}$ & 1.2 & $<0.01$ & $<0.01$ & 1.0 \\
\hline $4 \% \mathrm{FCM}^{2}(\mathrm{~kg} / \mathrm{d})$ & $31.42^{\mathrm{b}}$ & $34.91^{\mathrm{ab}}$ & $36.08^{\mathrm{a}}$ & 1.3 & 0.05 & $<0.01$ & 0.9 \\
\hline $\mathrm{FCM} / \mathrm{DMI}$ & 2.04 & 2.05 & 2.12 & 0.06 & 0.62 & 0.04 & 0.47 \\
\hline $\mathrm{NE}_{\mathrm{L}}$ balance $^{3}(\mathrm{Mcal} / \mathrm{d})$ & -7.10 & -7.41 & -8.72 & 0.9 & 0.2 & $<0.01$ & 0.3 \\
\hline MP balance $(\mathrm{g} / \mathrm{d})$ & $-440^{\mathrm{a}}$ & $-258^{\mathrm{b}}$ & $-127^{\mathrm{b}}$ & 39.6 & $<0.01$ & $<0.01$ & 0.4 \\
\hline \multicolumn{8}{|l|}{ Milk fat } \\
\hline \multicolumn{8}{|l|}{ Lactose } \\
\hline$\%$ & 4.27 & 4.31 & 4.35 & 0.05 & 0.3 & 0.01 & 0.7 \\
\hline $\mathrm{kg} / \mathrm{d}$ & $1.39^{\mathrm{b}}$ & $1.61^{\mathrm{a}}$ & $1.71^{\mathrm{a}}$ & 0.05 & $<0.01$ & $<0.01$ & 0.7 \\
\hline MUN $(\mathrm{m} M)$ & $5.05^{\mathrm{c}}$ & $5.51^{\mathrm{b}}$ & $6.04^{\mathrm{a}}$ & 0.06 & $<0.01$ & $<0.01$ & $<0.01$ \\
\hline Milk N secretion $(\mathrm{kg} / \mathrm{d})$ & $0.170^{\mathrm{b}}$ & $0.200^{\mathrm{a}}$ & $0.218^{\mathrm{a}}$ & 0.006 & $<0.01$ & $<0.01$ & 0.6 \\
\hline Milk N/N intake & $0.43^{\mathrm{a}}$ & $0.39^{\mathrm{b}}$ & $0.37^{\mathrm{b}}$ & 0.01 & $<0.01$ & $<0.01$ & 0.12 \\
\hline
\end{tabular}

\footnotetext{
${ }^{\mathrm{a}-\mathrm{c}}$ Means within same row with different superscripts differ $(P \leq 0.05)$.

${ }^{1}$ Diets designated as $16 \mathrm{CP}, 19 \mathrm{CP}$, and $21 \mathrm{CP}$ contained $16.0,18.7$, and $21.4 \% \mathrm{CP}$, respectively.

${ }^{2} 4 \% \mathrm{FCM}=[0.4 \times$ milk $(\mathrm{kg})]+[15 \times$ milk fat $(\mathrm{kg})]$.

${ }^{3} \mathrm{NE}_{\mathrm{L}}$ balance was calculated based on NRC (2001).
} 
Table 5. Effects of increasing dietary CP and RUP supply on total-tract apparent digestibility, and BW and BCS changes in fresh dairy cows

\begin{tabular}{|c|c|c|c|c|c|c|c|}
\hline \multirow[b]{2}{*}{ Item } & \multicolumn{3}{|c|}{ Diet $^{1}$} & \multirow[b]{2}{*}{ SEM } & \multicolumn{3}{|c|}{$P$-value } \\
\hline & $16 \mathrm{CP}$ & $19 \mathrm{CP}$ & $21 \mathrm{CP}$ & & Diet & Time & Diet $\times$ Time \\
\hline \multicolumn{8}{|c|}{ Apparent digestibility (\%) } \\
\hline $\mathrm{CP}$ & $69.2^{\mathrm{b}}$ & $72.6^{\mathrm{a}}$ & $72.8^{\mathrm{a}}$ & 0.8 & $<0.01$ & 0.8 & 0.8 \\
\hline $\mathrm{NDF}$ & $49.4^{\mathrm{b}}$ & $52.5^{\mathrm{a}}$ & $53.5^{\mathrm{a}}$ & 0.8 & $<0.01$ & 0.1 & 0.9 \\
\hline BW change (kg) & -67.6 & -42.2 & -65.7 & 11.1 & 0.2 & - & - \\
\hline
\end{tabular}

$\overline{\mathrm{a}, \mathrm{b}}$ Means within same row with different superscripts differ $(P \leq 0.05)$.

${ }^{1}$ Diets designated as $16 \mathrm{CP}, 19 \mathrm{CP}$, and $21 \mathrm{CP}$ contained $16.0,18.7$, and $21.4 \% \mathrm{CP}$, respectively.

between cows fed $19 \mathrm{CP}$ and $21 \mathrm{CP}$ diets (37.4 and 39.2 $\mathrm{kg} / \mathrm{d}$, respectively; Table 4). Yield of $4 \% \mathrm{FCM}$ was increased $(P=0.05)$ by the $21 \mathrm{CP}$ diet compared with the $16 \mathrm{CP}$ diet, but was similar between $16 \mathrm{CP}$ and $19 \mathrm{CP}$, and between $19 \mathrm{CP}$ and $21 \mathrm{CP}$ diets. Neither energy balance nor feed efficiency was affected by dietary CP levels $(P>0.1$; Table 4$)$.

It has been well documented that dietary $\mathrm{CP}$ content affects the productivity of dairy cows. In some studies (Leonardi et al., 2003; Colmenero and Broderick, 2006), milk production was not affected by dietary protein levels, in which diet CP ranged from 13.2 to $15.1 \%$ of DM compared with 16 to $18 \%$ of DM. The increased milk yield with $19 \mathrm{CP}$ and $21 \mathrm{CP}$ diets compared with $16 \mathrm{CP}$ diet is in accordance with previous studies (Law et al., 2009; Lee et al., 2011; Giallongo et al., 2016). Increase in DMI with the high CP diets was responsible for increased milk yield in the present study because DMI is one of the most important determinants for milk yield (Hristov et al., 2004). Moreover, improved supply of MP and digestible AA (particularly Met, Lys, Leu, and His) may account, in part, for the increase in milk yield, as was reported by other studies (Doepel et al., 2004; Garnsworthy et al., 2008).

The supply of protein below requirements may reduce milk yield and protein content (Lee et al., 2012a). Previous experiments (Cabrita et al., 2011; Giallongo et al., 2016) reported that MP-deficient diets decreased milk yield compared with MP-adequate diets, despite diets being balanced for absorbable AA. In some cases, however, supplementation of MP-deficient diets with rumen-protected AA successfully maintained milk and component yields (Broderick et al., 2008; Lee et al., 2015; Patton et al., 2015). In our study, production responses to protein supplementation in the diet were larger than in some previous reports (Broderick, 2003; Cabrita et al., 2011; Lee et al., 2011), supporting the hypothesis that cows in the earliest stages of lactation show the greatest responses to improved AA supply where the balance for absorbed AA is most negative (Socha et al., 2005; Galindo et al., 2015), but the re- sponse magnitude to supplement dietary protein decreases as lactation progress (Wu and Satter, 2000).

In the current study, cows fed the $19 \mathrm{CP}$ and $21 \mathrm{CP}$ diets produced more milk than cows fed the $16 \mathrm{CP}$ diet: $4.7 \pm 1.5 \mathrm{~kg} / \mathrm{d}$ and $6.5 \pm 2.5 \mathrm{~kg} / \mathrm{d}$, respectively. This increase began on d 4 of lactation and and was sustained until d 21 of lactation (Figure 1). Although apoptosis of alveolar cells in early lactation might be reduced by additional supply of protein (Larsen et al., 2014), the extent to which protein supply was used for cell proliferation or milk synthesis (lactogenesis) is unclear.

Milk protein content and yield increased $(P<0.05$; Table 4) with increasing dietary $\mathrm{CP}$ from 16.0 to $21.0 \%$ of DM using RUP supplements. In the current study, increasing dietary CP levels with FM and CGM provided an improved supply of AA to the duodenum (Table 3). The increased milk protein content and yield might be due to improved supply of Met, Lys, Leu, and His. These findings are in line with some previous studies that have showed positive responses in milk protein content to supplementation of Met (Socha et al., 2005, 2008; Ordway et al., 2009), Lys (Lapierre et al., 2009), and His (Weekes et al., 2006) in diets deficient in these AA. In addition, Leu is a potent stimulator of the mammalian target of rapamycin (mTOR) within the mammary cells (Appuhamy et al., 2012; Suryawan et al., 2012), so greater supply of Leu to mammary gland in the current study may increase milk protein synthesis through phosphorylation of mTOR (Doelman et al., 2015).

Milk fat content tended to decrease $(P=0.10$; Table 4) with increasing content of $\mathrm{CP}$ in diets, but milk fat yield was not affected by dietary treatments $(P=0.15$; Table 4). Similar results have been reported by some (Mattos et al., 2002) but not others (Haque et al., 2012; Lee et al., 2012b). The decreased milk fat content with increasing dietary CP levels in the present study can be due to a dilution effect caused by an increase in milk yield.

Although the content of lactose was similar $(P=$ 0.32; Table 4) among diets, high CP diets increased 


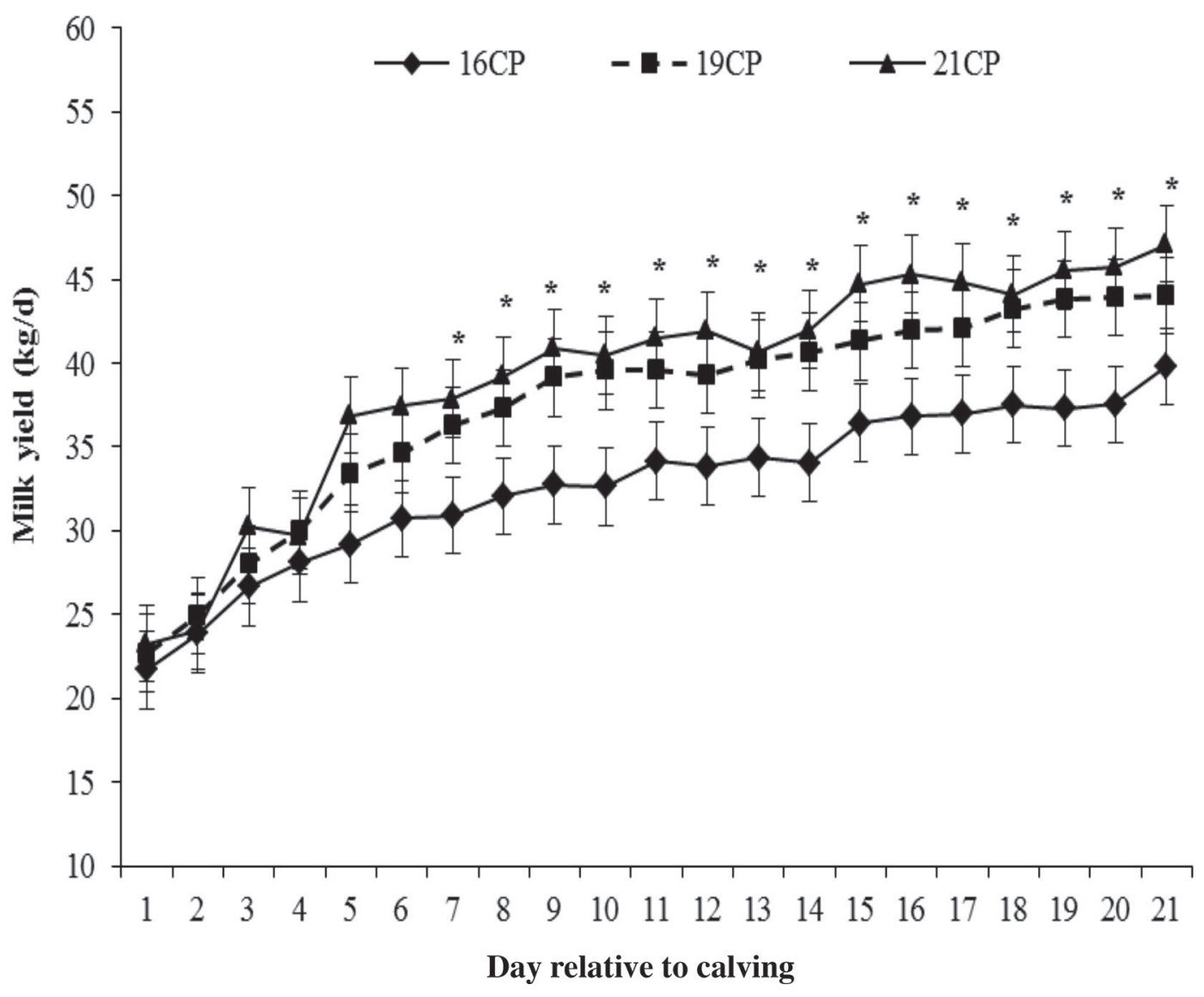

Figure 1. Effects of increasing dietary CP and RUP supply on milk yield in fresh cows. Diets designated as 16CP, 19CP, and 21CP contained 16.0, 18.7, and 21.4\% CP, respectively. Data are presented as least squares means and SEM. For each time point, asterisks indicate differences among dietary treatments: $* P \leq 0.05$.

milk lactose yield $(P<0.01$; Table 4$)$, which is in agreement with increased milk yields. These observations agree with other studies (Cabrita et al., 2011; Larsen et al., 2014).

Cows fed $19 \mathrm{CP}$ and $21 \mathrm{CP}$ had higher milk N secretion and lower milk $\mathrm{N}$ efficiency compared with cows fed 16CP $(P<0.01$; Table 4$)$. These observed effects appear to be due to higher DM and protein intakes with high $\mathrm{CP}$ diets relative to $16 \mathrm{CP}$ diet. Moreover, the increase in $\mathrm{N}$ intake with increasing dietary $\mathrm{CP}$ was greater than increase in milk $\mathrm{N}$ secretion, so the efficiency of milk $\mathrm{N}$ decreased as $\mathrm{CP}$ levels increased from 16 to $21 \%$ of DM in diets. These results are consistent with others (Broderick, 2003; Law et al., 2009; Lee et al., 2011).

Milk urea nitrogen increased with increasing dietary CP levels $(P<0.01$; Table 4$)$, in agreement with most of the literature (Brown and Allen, 2013; Larsen et al., 2014; Lee et al., 2015). The interaction of diet by time indicated that cows in $21 \mathrm{CP}$ diet had higher MUN concentrations than $16 \mathrm{CP}$ and $19 \mathrm{CP}$ diets during the first

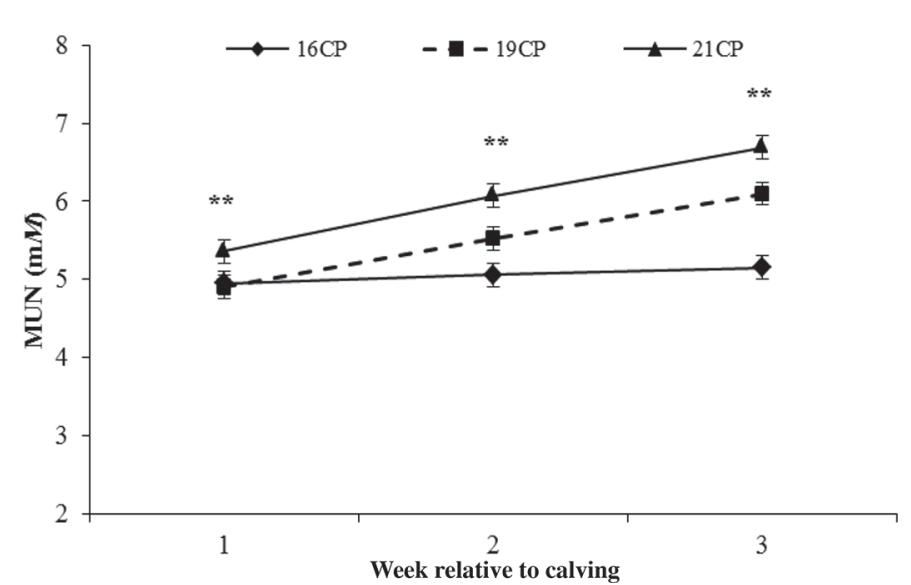

Figure 2. Effects of increasing dietary $\mathrm{CP}$ and RUP supply on MUN concentrations in fresh cows. Diets designated as $16 \mathrm{CP}, 19 \mathrm{CP}$, and $21 \mathrm{CP}$ contained $16.0,18.7$, and $21.4 \% \mathrm{CP}$, respectively. Data are presented as least squares means and SEM. For each time point, asterisks indicate differences among dietary treatments: ${ }^{* *} P<0.01$. 
3 wk after calving. Although cows in $16 \mathrm{CP}$ and $19 \mathrm{CP}$ had similar MUN at wk 1 relative to calving, MUN level was higher for $19 \mathrm{CP}$ diet than for $16 \mathrm{CP}$ diet at wk 2 and 3 relative to calving (Figure 2).

Increased MUN concentrations are a function of dietary CP content, ruminal protein degradability, postruminal supply of protein (Jonker et al., 1998), and energy intake (Jordan et al., 1983; Oltner et al., 1985). Because cows in this experiment consumed different amounts of RDP and RUP, the increased MUN concentrations in cows fed the 19CP and $21 \mathrm{CP}$ diets could be due to ruminal metabolism of protein and hepatic oxidation of AA absorbed in excess of requirements for glucose production, or both. A similar response was observed for the concentrations of MUN in the first week after calving between $16 \mathrm{CP}$ and $19 \mathrm{CP}$. This could reflect greater body protein mobilization for cows in the 16CP diet during the negative protein balance period that is in agreement with reports of other researchers (Wattiaux and Karg, 2004; Rastani et al., 2006).

\section{Total-Tract Apparent Digestibility}

There was difference in total-tract apparent digestibility of DM, CP, and NDF with increasing dietary CP levels $(P<0.01$; Table 5$)$, as cows fed $19 \mathrm{CP}$ and $21 \mathrm{CP}$ diets had higher nutrient digestibility than cows fed the $16 \mathrm{CP}$ diet. Similar results are reported by Broderick et al. (2008), Broderick and Reynal (2009), and Lee et al. (2011, 2012a). Fiber digestibility was decreased by $16 \mathrm{CP}$ diet in the current study, which might be due to RDP deficiency. Another factor that could have contributed to decreased nutrient digestibility in $16 \mathrm{CP}$ diet was lower DMI because fermentable energy stimulates microbial fermentation (NRC, 2001) and the lower DMI on $16 \mathrm{CP}$ diet may have impaired microbial activity and growth (Lee et al., 2012a).

\section{$B W$ and $B C S$}

In agreement with Lee et al. (2011) and Larsen et al. (2014), different CP levels $(P>0.05$; Table 5$)$ had no effect on live BW change, but body condition change was affected by treatments $(P<0.01$; Table 5$)$, as cows fed the $19 \mathrm{CP}$ and $21 \mathrm{CP}$ diets had smaller body condition losses compared with cows fed the $16 \mathrm{CP}$ diet. This result is supported by decreased NEFA (Table 6) for cows fed $19 \mathrm{CP}$ and $21 \mathrm{CP}$ relative to $16 \mathrm{CP}$ that indicate an improvement in the indicators of metabolic status in cows fed high CP diets.

\section{Blood Metabolites}

The effects of different levels of dietary $\mathrm{CP}$ on blood metabolites are presented in Table 6. Serum TP, albumin, albumin to globulin ratio, and BUN concentrations were evaluated as biomarkers of protein metabolism, and their concentrations reflect protein status. Serum concentration of TP tended to be greater in cows fed $19 \mathrm{CP}$ and $21 \mathrm{CP}$ diets relative to $16 \mathrm{CP}$ treatment $(P=$ $0.1 ; 7.1$ and 7.1 vs. $6.8 \mathrm{~g} / \mathrm{dL})$. Increasing dietary CP increased serum albumin $(P=0.02)$, albumin to globulin ratio $(P=0.04)$, and BUN $(P<0.01)$ concentrations, but had no effect on globulin $(P=0.9)$. These results are in agreement with some studies conducted during early lactation (Raggio et al., 2007; Law et al., 2009), but no effects of feeding protein on plasma TP or albumin have been reported in mid (Cabrita et al., 2011) or late (Law et al., 2009) lactation. The concentrations of blood urea in most of the studies were increased with different CP levels (Bach et al., 2000; Cabrita et al., 2011; Larsen et al., 2014). Strang et al. (1998) reported that hepatic ureagenesis was decreased $40 \%$ through exposure of bovine hepatocytes to NEFA, and the toxic levels of ammonia have been known to inhibit the

Table 6. Effects of increasing dietary CP and RUP supply on blood metabolites in fresh dairy cows

\begin{tabular}{|c|c|c|c|c|c|c|c|}
\hline \multirow[b]{2}{*}{ Item } & \multicolumn{3}{|c|}{ Diet $^{1}$} & \multirow[b]{2}{*}{ SEM } & \multicolumn{3}{|c|}{$P$-value } \\
\hline & $16 \mathrm{CP}$ & $19 \mathrm{CP}$ & $21 \mathrm{CP}$ & & Diet & Time & Diet $\times$ Time \\
\hline Total protein $(\mathrm{g} / \mathrm{L})$ & 68.5 & 71.4 & 71.2 & 1.0 & 0.1 & $<0.01$ & 0.6 \\
\hline Albumin $(\mathrm{g} / \mathrm{L})$ & $31.1^{\mathrm{b}}$ & $34.1^{\mathrm{a}}$ & $33.9^{\mathrm{a}}$ & 0.7 & 0.02 & $<0.01$ & 0.6 \\
\hline Globulin $(\mathrm{g} / \mathrm{L})$ & 37.2 & 37.0 & 37.5 & 0.7 & 0.9 & 0.1 & 0.2 \\
\hline Albumin:globulin ratio & $0.83^{\mathrm{b}}$ & $0.93^{\mathrm{a}}$ & $0.91^{\mathrm{ab}}$ & 0.03 & 0.04 & $<0.01$ & 0.5 \\
\hline BUN $(\mathrm{m} M)$ & $5.50^{\mathrm{c}}$ & $6.3^{\mathrm{b}}$ & $7.2^{\mathrm{a}}$ & 0.14 & $<0.01$ & $<0.01$ & 0.4 \\
\hline Aspartate aminotransferase (U/L) & $124.4^{\mathrm{a}}$ & $96.5^{\mathrm{b}}$ & $87.5^{\mathrm{b}}$ & 6.0 & $<0.01$ & $<0.01$ & 0.11 \\
\hline Nonesterified fatty acids $(\mathrm{m} M)$ & $0.81^{\mathrm{a}}$ & $0.61^{\mathrm{b}}$ & $0.67^{\mathrm{b}}$ & 0.03 & $<0.01$ & $<0.01$ & 0.2 \\
\hline $\mathrm{BHB}(\mathrm{m} M)$ & $0.93^{\mathrm{a}}$ & $0.57^{\mathrm{b}}$ & $0.49^{\mathrm{b}}$ & 0.03 & $<0.01$ & $<0.01$ & 0.17 \\
\hline Cholesterol (mM) & 3.18 & 3.38 & 3.21 & 0.09 & 0.2 & $<0.01$ & 0.9 \\
\hline Triglyceride $(\mathrm{m} M)$ & 0.32 & 0.28 & 0.29 & 0.01 & 0.2 & $<0.01$ & 0.9 \\
\hline Glucose $(\mathrm{m} M)$ & 2.79 & 3.04 & 3.08 & 0.10 & 0.16 & $<0.01$ & 0.4 \\
\hline
\end{tabular}

${ }^{a-c}$ Means within same row with different superscripts differ $(P \leq 0.05)$.

${ }^{1}$ Diets designated as $16 \mathrm{CP}, 19 \mathrm{CP}$, and $21 \mathrm{CP}$ contained $16.0,18.7$, and $21.4 \% \mathrm{CP}$, respectively. 
gluconeogenesis process (Rodriguez et al., 1997). Thus, decreased NEFA and increased BUN concentrations for cows fed the $19 \mathrm{CP}$ and $21 \mathrm{CP}$ diets imply a possible improvement in hepatic NEFA metabolism and urea synthesis during the fresh period.

Cows fed the 19CP and 21CP diets had lower serum concentrations of AST than cows fed the $16 \mathrm{CP}$ diet $(P$ $<0.01$; Table 6$)$. These results are in accordance with decreased NEFA for cows fed high CP diets, as a positive correlation between plasma NEFA concentration and AST activity was reported by Chamberlin et al. (2013).

Serum NEFA and BHB concentrations were affected by dietary treatments and time $(P<0.01)$ but not by their interactions $(P>0.1$; Table 6$)$. Cows fed the 19CP and 21CP diets had lower serum NEFA and BHB than cows fed the 16CP diet, whereas these were similar between the 19CP and $21 \mathrm{CP}$ diets. Although there was no significant effect of treatment by time interaction on serum concentrations of NEFA and BHB in the current study, some least squares means combinations of treatment by time interaction were significant (Figure 3 ). In agreement with our results, Law et al. (2009) reported that increasing dietary CP from 11.4 to $17.3 \%$ of DM decreased plasma BHB from 0.55 to $0.47 \mathrm{~m} M$ during early and mid lactation (1 to 150 DIM).

In the current study, the reduction in serum NEFA for cows fed high $\mathrm{CP}$ diets may be attributed to the increase in DMI, decreasing the cow's need to depend on mobilized lipid to meet energy demands, which was also reflected in the smaller body condition losses. Moreover, a better duodenal balance of AA (i.e., Met and Lys) may partly contribute to the reduction of NEFA concentrations (Socha et al., 2008). Some studies reported a decrease in concentrations of plasma NEFA when intestinal supply of Met was linearly increased in cows with DIM less than 50 (Socha, 1994; Pisulewski et al., 1996), but not in peak- or mid-lactation cows (Socha et al., 2008). This indicates a greater requirement for Met in postpartum cows because of its potential role in lipid metabolism as methyl group donor (Pinotti et al., 2002). The higher BHB in cows fed the 16CP diet compared with high $\mathrm{CP}$ diets could be explained by NEFA flow into the liver and the limited oxidation capacity of hepatocytes (Emery et al., 1992), resulting in the release of ketone bodies as energetic sources for milk fat synthesis. This result is in agreement with milk fat content findings (Table 4).
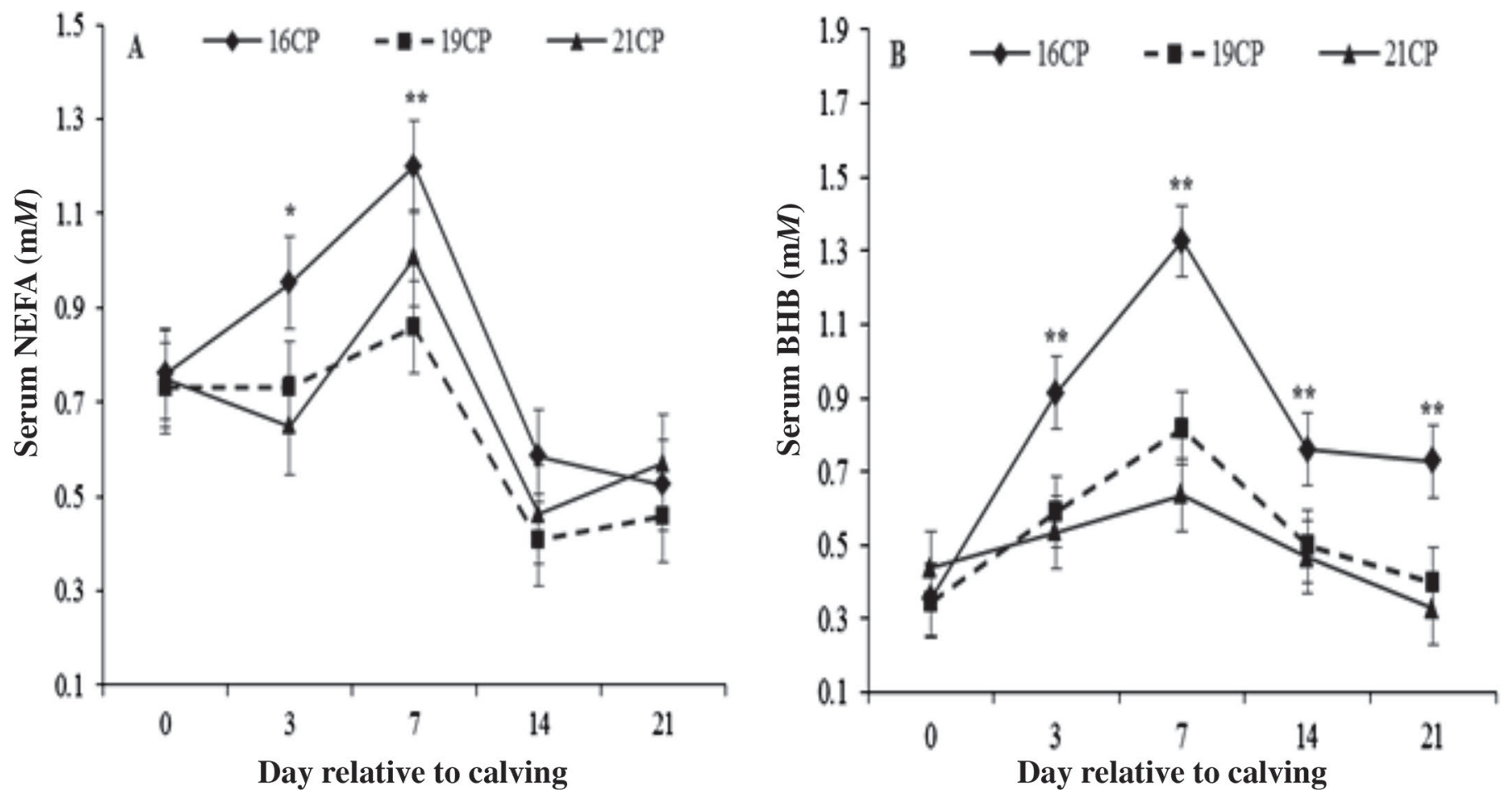

Figure 3. Effects of increasing dietary CP and RUP supply on (A) serum nonesterified fatty acids (NEFA) and (B) serum BHB concentrations of dairy cows during the fresh period. Diets designated as $16 \mathrm{CP}, 19 \mathrm{CP}$, and $21 \mathrm{CP}$ contained $16.0,18.7$, and $21.4 \% \mathrm{CP}$, respectively. Data are presented as least squares means and SEM. For each time point, asterisks indicate differences among dietary treatments: $* P \leq 0.05$ or $* * P$ $<0.01$. 
The concentrations of serum glucose were not affected by dietary CP levels $(P>0.05$; Table 6$)$, as has been reported by other authors (Law et al., 2009; Cabrita et al., 2011; Lee et al., 2011). There was a effect of time on serum glucose $(P<0.01)$. In this study, serum glucose peaked at calving $(5.05 \mathrm{mM})$ and reached its nadir at 3 DIM $(2.49 \mathrm{mM})$. This is probably related to calving physiological changes that increase gluconeogenesis to supply greater glucose to meet the mammary gland demands for milk yield (Garverick et al., 2013).

Serum cholesterol and TAG concentrations were not affected by dietary treatments $(P>0.05)$, but there was a effect of time on serum cholesterol and TAG ( $P$ $<0.01$; Table 6 ). Serum cholesterol levels in all dietary treatments followed a similar pattern, and increased from calving to 21 DIM, from 2.21 to $3.78 \mathrm{mM}$. Serum TAG concentrations had a peak at calving $(0.51 \mathrm{mM})$ and reached its nadir levels at 21 DIM $(0.21 \mathrm{mM})$. In agreement with our findings, Bahrami-Yekdangi et al. (2014) observed similar TAG concentrations independent of the dietary CP levels.

\section{CONCLUSIONS}

Increasing dietary CP levels up to $19 \%$ of DM increased DMI, milk yield, and the yields of milk protein and lactose. High CP diets increased MUN, N intake and milk $\mathrm{N}$ secretion, but decreased milk $\mathrm{N}$ efficiency. Apparent digestibility of DM, CP, and NDF was greater in the $19 \mathrm{CP}$ and $21 \mathrm{CP}$ diets than in the $16 \mathrm{CP}$ diet. Feeding high CP diets increased the concentrations of serum albumin, albumin to globulin ratio, and BUN, decreased NEFA and BHB, but had no effect on globulin, glucose, cholesterol, or triacylglycerol. The responses observed in the present study indicate that increasing protein supply using RUP supplements immediately after calving can have beneficial effects on productive performance and indicators of protein and energy status in fresh cows. Due to the potential to decrease NEFA and BHB concentrations, the effects of additional protein supply on liver health and ketosis incidence in peripartum cows warrant further investigations.

\section{ACKNOWLEDGMENTS}

The authors thank Roger Martineau (Dairy Production Centre; Sherbrooke, QC, Canada) for his scientific assistance during the preparation of this manuscript. We also thank James Drackley (Department of Animal Sciences, University of Illinois, Urbana) for his invaluable comments on this paper.

\section{REFERENCES}

Allen, M. S. 2000. Effects of diet on short-term regulation of feed intake by lactating dairy cattle. J. Dairy Sci. 83:1598-1624.

Allen, M. S., B. J. Bradford, and M. Oba. 2009. The hepatic oxidation theory of the control of feed intake and its application to ruminants. J. Anim. Sci. 87:3317-3334.

Allen, M. S., and P. Piantoni. 2013. Metabolic control of feed intake: Implications for metabolic disease of fresh cows. Vet. Clin. North Am. Food Anim. Pract. 29:279-297.

AOAC. 1990. Official Methods of Analysis. 15th ed. Association of Official Analytical Chemists, Arlington, VA.

Appuhamy, J. A., N. A. Knoebel, W. A. D. Nayananjalie, J. Escobar, and M. D. Hanigan. 2012. Isoleucine and leucine independently regulate mTOR signalling and protein synthesis in MAC-T cells and bovine mammary tissue slices. J. Nutr. 142:484-491.

Bach, A., G. Huntington, S. Calsamiglia, and M. Stern. 2000. Nitrogen metabolism of early lactation cows fed diets with two different levels of protein and different amino acid profiles. J. Dairy Sci. $83: 2585-2595$

Bahrami-Yekdangi, H., M. Khorvash, G. Ghorbani, M. Alikhani, R. Jahanian, and E. Kamalian. 2014. Effects of decreasing metabolizable protein and rumen-undegradable protein on milk production and composition and blood metabolites of Holstein dairy cows in early lactation. J. Dairy Sci. 97:3707-3714.

Bell, A. W., W. S. Burhans, and T. R. Overton. 2000. Protein nutrition in late pregnancy, maternal protein reserves and lactation performance in dairy cows. Proc. Nutr. Soc. 59:119-126.

Bergmeyer, H. U. N., M. Horder, and R. Rej. 1986. International federation of clinical chemistry (IFCC) scientific committee analytical section: Approved recommendation on IFCC method for measurement of catalytic concentration of enzyme, part 2: IFCC method for aspartate aminotransferase. J. Clin. Chem. Clin. Biochem. 24:497-510.

Broderick, G. A. 2003. Effects of varying dietary protein and energy levels on the production of lactating dairy cows. J. Dairy Sci. 86:1370-1381.

Broderick, G. A., D. Mertens, and R. Simons. 2002. Efficacy of carbohydrate sources for milk production by cows fed diets based on alfalfa silage. J. Dairy Sci. 85:1767-1776.

Broderick, G. A., and S. Reynal. 2009. Effect of source of rumen-degraded protein on production and ruminal metabolism in lactating dairy cows. J. Dairy Sci. 92:2822-2834.

Broderick, G. A., M. Stevenson, R. Patton, N. Lobos, and J. O. Colmenero. 2008. Effect of supplementing rumen-protected methionine on production and nitrogen excretion in lactating dairy cows. J. Dairy Sci. 91:1092-1102.

Brown, W. E., and M. S. Allen. 2013. Effects of intrajugular glucose infusion on feed intake, milk yield, and metabolic responses of early postpartum cows fed diets varying in protein and starch concentration. J. Dairy Sci. 96:7132-7142.

Cabrita, A. R. J., R. J. Dewhurst, D. S. P. Melo, J. M. Moorby, and A. J. M. Fonseca. 2011. Effects of dietary protein concentration and balance of absorbable amino acids on productive responses of dairy cows fed corn silage-based diets. J. Dairy Sci. 94:4647-4656.

Carra, M., B. Al-Trad, G. B. Penner, T. Wittek, G. Gabel, M. Fürll and J. R. Aschenbach. 2013. Intravenous infusion of glucose stimulate key lipogenic enzymes in adipose tissue of dairy cows in a dose-dependent manner. J. Dairy Sci. 96:4299-4309.

Chamberlin, W. G., J. Middleton, J. Spain, G. Johnson, M. Ellersieck, and P. Pithua. 2013. Subclinical hypocalcemia, plasma biochemical parameters, lipid metabolism, postpartum disease, and fertility in postparturient dairy cows. J. Dairy Sci. 96:7001-7013.

Chibisa, G. E., G. Gozho, A. Van Kessel, A. Olkowski, and T. Mutsvangwa. 2008. Effects of peripartum propylene glycol supplementation on nitrogen metabolism, body composition, and gene expression for the major protein degradation pathways in skeletal muscle in dairy cows. J. Dairy Sci. 91:3512-3527.

Cole, T. G., S. G. Klotzsch, and J. R. McNamara. 1997. Measurement of triglyceride concentration. Pages 115-126 in Handbook of Lipo- 
protein Testing. N. Rifai, G. R. Warnick, and M. H. Dominiczak, ed. AACC Pres, Washington, DC.

Colmenero, J. J., and G. Broderick. 2006. Effect of dietary crude protein concentration on ruminal nitrogen metabolism in lactating dairy cows. J. Dairy Sci. 89:1694-1703.

Cunningham, K. D., M. Cecava, T. Johnson, and P. Ludden. 1996. Influence of source and amount of dietary protein on milk yield by cows in early lactation. J. Dairy Sci. 79:620-630.

Deeg, R., and J. Ziegenhorn. 1983. Kinetic enzymatic method for automated determination of total cholesterol in serum. Clin. Chem. 29:1798-1802.

DeVries, G. H., P. Mamunes, C. D. Miller, and D. M. Hayward. 1976. Quantitative determination of C6:0-C18:3 serum nonesterified fatty acids by gas-liquid chromatography. Anal. Biochem. 70:156-166.

Doelman, J., J. J. Kim, M. Carson, J. A. Metcalf, and J. P. Cant. 2015. Branched-chain amino acid and lysine deficiencies exert different effects on mammary translational regulation. J. Dairy Sci. 98:7846-7855.

Doepel, L., D. Pacheco, J. J. Kennelly, M. D. Hanigan, I. F. Lopez, and H. Lapierre. 2004. Milk protein synthesis as a function of amino acid supply. J. Dairy Sci. 87:1279-1297.

Edmonson, A., I. Lean, L. Weaver, T. Farver, and G. Webster. 1989. A body condition scoring chart for Holstein dairy cows. J. Dairy Sci. 72:68-78.

Emery, R. S., J. S. Liesman, and T. H. Herdt. 1992. Metabolism of long chain fatty acids by ruminant liver. J. Nutr. 122:832-837.

Flis, S. A., and M. Wattiaux. 2005. Effects of parity and supply of rumen-degraded and undegraded protein on production and nitrogen balance in Holsteins. J. Dairy Sci. 88:2096-2106.

Galindo, C., M. Larsen, D. R. Ouellet, G. Maxin, D. Pellerin, and H. Lapierre. 2015. Abomasal amino acid infusion in postpartum dairy cows: Effect on whole-body, splanchnic, and mammary glucose metabolism. J. Dairy Sci. 98:7962-7974.

Garnsworthy, P. C., J. Gong, D. Armstrong, J. Newbold, M. Marsden, S. Richards, G. Mann, K. Sinclair, and R. Webb. 2008. Nutrition, metabolism, and fertility in dairy cows: 3 . Amino acids and ovarian function. J. Dairy Sci. 91:4190-4197.

Garverick, H. A., M. Harris, R. Vogel-Bluel, J. Sampson, J. Bader, W. Lamberson, J. Spain, M. Lucy, and R. Youngquist. 2013. Concentrations of nonesterified fatty acids and glucose in blood of periparturient dairy cows are indicative of pregnancy success at first insemination. J. Dairy Sci. 96:181-188.

Giallongo, F., M. T. Harper, J. Oh, J. C. Lopes, H. Lapierre, R. A. Patton, C. Parys, I. Shinzato, and A. N. Hristov. 2016. Effects of rumen-protected methionine, lysine, and histidine on lactation performance of dairy cows. J. Dairy Sci. 99:4437-4452.

Grummer, R. R. 1995. Impact of changes in organic nutrient metabolism on feeding the transition dairy cow. J. Anim. Sci. 73:28202833.

Haque, M. N., H. Rulquin, A. Andrade, P. Faverdin, J. L. Peyraud, and S. Lemosquet. 2012. Milk protein synthesis in response to the provision of an "ideal" amino acid profile at 2 levels of metabolizable protein supply in dairy cows. J. Dairy Sci. 95:5876-5887.

Hristov, A. N., W. Price, and B. Shafii. 2004. A meta-analysis examining the relationship among dietary factors, dry matter intake, and milk and milk protein yield in dairy cows. J. Dairy Sci. $87: 2184-2196$

Huhtanen, P., and M. Hetta. 2012. Comparison of feed intake and milk production responses in continuous and change-over design dairy cow experiments. Livest. Sci. 143:184-194.

Ji, P., and H. M. Dann. 2013. Negative Protein Balance: Implications for Transition Cows. Pages 101-112 in Proc. Cornell Nutrition Conference Cornell University, NY, Syracuse, NY.

Johnson, A. M., E. M. Rohlfs, and L. M. Silverman. 1999. Protein. Pages 477-540 in Tietz Textbook of Clinical Chemistry. 3rd ed. C. A. Burtis, and E. R. Ashwood, ed. Saunders Co., Philadelphia, PA.

Jonker, J. S., R. Kohn, and R. Erdman. 1998. Using milk urea nitrogen to predict nitrogen excretion and utilization efficiency in lactating dairy cows. J. Dairy Sci. 81:2681-2692.
Jordan, E. R., T. E. Chapman, D. W. Holtan, and L. V. Swanson. 1983. Relationship of dietary crude protein to composition of uterine secretions and blood in high-producing postpartum dairy cows. J. Dairy Sci. 66:1854-1862.

Komaragiri, M. V., D. Casper, and R. Erdman. 1998. Factors affecting body tissue mobilization in early lactation dairy cows. 2. Effect of dietary fat on mobilization of body fat and protein. J. Dairy Sci. $81: 169-175$.

Kröber, T., M. Kreuzer, M. Senn, W. Langhans, and F. Sutter. 2000. Effects of rumen protected methionine in a low protein ration on metabolic traits and performance of early lactating cows as opposed to rations with elevated crude protein content. J. Anim. Physiol. Anim. Nutr. (Berl.) 84:148-164.

Lapierre, H., L. Doepel, E. Milne, and G. E. Lobley. 2009. Responses in mammary and splanchnic metabolism to altered lysine supply in dairy cows. Animal 3:360-371.

Larsen, M., and N. B. Kristensen. 2009. Effect of abomasal glucose infusion on splanchnic and whole-body glucose metabolism in periparturient dairy cows. J. Dairy Sci. 92:1071-1083.

Larsen, M., H. Lapierre, and N. B. Kristensen. 2014. Abomasal protein infusion in postpartum transition dairy cows: Effect on performance and mammary metabolism. J. Dairy Sci. 97:5608-5622.

Law, R. A., F. Young, D. Patterson, D. Kilpatrick, A. Wylie, and C. Mayne. 2009. Effect of dietary protein content on animal production and blood metabolites of dairy cows during lactation. J. Dairy Sci. 92:1001-1012.

Lee, C., F. Giallongo, A. Hristov, H. Lapierre, T. Cassidy, K. Heyler, G. Varga, and C. Parys. 2015. Effect of dietary protein level and rumen-protected amino acid supplementation on amino acid utilization for milk protein in lactating dairy cows. J. Dairy Sci. 98:1885-1902.

Lee, C., A. Hristov, K. Heyler, T. Cassidy, H. Lapierre, G. Varga, and C. Parys. 2012a. Effects of metabolizable protein supply and amino acid supplementation on nitrogen utilization, milk production, and ammonia emissions from manure in dairy cows. J. Dairy Sci. 95:5253-5268.

Lee, C., A. Hristov, K. Heyler, T. Cassidy, M. Long, B. Corl, and S. Karnati. 2011. Effects of dietary protein concentration and coconut oil supplementation on nitrogen utilization and production in dairy cows. J. Dairy Sci. 94:5544-5557.

Lee, C., A. N. Hristov, T. W. Cassidy, K. S. Heyler, H. Lapierre, G. A. Varga, M. J. de Veth, R. A. Patton, and C. Parys. 2012b. Rumenprotected lysine, methionine, and histidine increase milk protein yield in dairy cows fed a metabolizable protein-deficient diet. J. Dairy Sci. 95:6042-6056.

Leonardi, C., M. Stevenson, and L. Armentano. 2003. Effect of two levels of crude protein and methionine supplementation on performance of dairy cows. J. Dairy Sci. 86:4033-4042.

Littell, R. C., P. Henry, and C. Ammerman. 1998. Statistical analysis of repeated measures data using SAS procedures. J. Anim. Sci. $76: 1216-1231$.

Martineau, R., D. R. Ouellet, E. Kebreab, and H. Lapierre. 2016. Casein infusion rate influences feed intake differently depending on metabolizable protein balance in dairy cows: A multilevel metaanalysis. J. Dairy Sci. 99:2748-2761.

Mattos, R., C. R. Staples, J. Williams, A. Amorocho, M. A. McGuire, and W. W. Thatcher. 2002. Uterine, ovarian, and production responses of lactating dairy cows to increasing dietary concentrations of menhaden fish meal. J. Dairy Sci. 85:755-764.

McMurray, C. H., W. J. Blanchflower, and D. A. Rice. 1984. Automated kinetic method for D-3-hydroxybutyrate in plasma or serum. Clin. Chem. 30:421-425.

NRC. 2001. Nutrient Requirements of Dairy Cattle. 7th rev. ed. Natl. Acad. Sci., Washington, DC.

Oba, M., and M. S. Allen. 2003. Hypophagic effects of ammonium are greater when infused with propionate compared with acetate in lactating dairy cows. J. Nutr. 133:1100-1104.

Oltner, R., M. Emanuelson, and H. Wiktorsson. 1985. Urea concentration in milk in relation to milk yield, live weight, lactation number, and amount and composition of feed given to dairy cows. Livest. Prod. Sci. 12:47-52. 
Ordway, R. S., S. E. Boucher, N. L. Whitehouse, C. G. Schwab, and B. K. Sloan. 2009. Effects of providing two forms of supplemental methionine to periparturient Holstein dairy cows on feed intake and lactational performance. J. Dairy Sci. 92:5154-5166.

Ørskov, E. R., D. A. Grubb, and R. N. B. Kay. 1977. Effect of postruminal glucose or protein supplementation on milk yield and composition in Friesian cows in early lactation and negative energy balance. Br. J. Nutr. 38:397-405.

Ouellet, D. R., G. E. Lobley, and H. Lapierre. 2014. Histidine requirement of dairy cows determined by the indicator amino acid oxidation (AAO) technique. J. Dairy Sci. 97(Suppl. 1):757. (Abstr.)

Overton, T. R., J. K. Drackley, C. J. Ottemann-Abbamonte, A. D. Beaulieu, L. S. Emmert, and J. H. Clark. 1999. Substrate utilization for hepatic gluconeogenesis is altered by increased glucose demand in ruminants. J. Anim. Sci. 77:1940-1951.

Owens, F., S. Qi, and D. Sapienza. 2014. Invited Review: Applied protein nutrition of ruminants-Current status and future directions. Prof. Anim. Sci. 30:150-179.

Patton, R. A., A. N. Hristov, C. Parys, and H. Lapierre. 2015. Relationships between circulating plasma concentrations and duodenal flows of essential amino acids in lactating dairy cows. J. Dairy Sci. 98:4707-4734

Pinotti, L., A. Baldi, and V. Dell'Orto. 2002. Comparative mammalian choline metabolism with emphasis on the high-yielding dairy cow. Nutr. Res. Rev. 15:315-332.

Pisulewski, P. M., H. Rulquin, J. L. Peyraud, and R. Verité. 1996. Lactational and systemic responses of dairy cows to postruminal infusions of increasing amounts of methionine. J. Dairy Sci. 79:1781-1791.

Raggio, G., G. Lobley, R. Berthiaume, D. Pellerin, G. Allard, P. Dubreuil, and H. Lapierre. 2007. Effect of protein supply on hepatic synthesis of plasma and constitutive proteins in lactating dairy cows. J. Dairy Sci. 90:352-359.

Rastani, R. R., N. E. Lobos, M. J. Aguerre, R. R. Grummer, and M. A. Wattiaux. 2006. Relationships between blood urea nitrogen and energy balance or measures of tissue mobilization in Holstein cows during the periparturient period. Prof. Anim. Sci. 22:382-385.

Rodriguez, L. A., C. Stallings, J. Herbein, and M. McGilliard. 1997. Effect of degradability of dietary protein and fat on ruminal, blood, and milk components of Jersey and Holstein cows. J. Dairy Sci. 80:353-363.

Socha, M. T. 1994. Determining the methionine requirements of lactating dairy cows. PhD Thesis. University of New Hampshire, Durham.

Socha, M. T., D. E. Putnam, B. D. Garthwaite, N. L. Whitehouse, N. A. Kierstead, C. G. Schwab, G. A. Ducharme, and J. C. Robert.
2005. Improving intestinal amino acid supply of pre-and postpartum dairy cows with rumen-protected methionine and lysine. J. Dairy Sci. 88:1113-1126.

Socha, M. T., C. G. Schwab, D. E. Putnam, N. L. Whitehouse, B D. Garthwaite, and G. A. Ducharme. 2008. Extent of methionine limitation in peak-, early-, and mid-lactation dairy cows. J. Dairy Sci. 91:1996-2010.

Strang, B. D., S. Bertics, R. Grummer, and L. Armentano. 1998. Effect of long-chain fatty acids on triglyceride accumulation, gluconeogenesis, and ureagenesis in bovine hepatocytes. J. Dairy Sci $81: 728-739$.

Suryawan, A., R. M. Torrazza, M. C. Gazzaneo, R. A. Orellana, M. L. Fiorotti, S. W. El-Kadi, N. Srivastava, H. V. Nguyen, and T. A. Davis. 2012. Enteral leucine supplementation increases protein synthesis in skeletal and cardiac muscles and visceral tissues of neonatal pigs through mTORC 1-dependent pathways. Pediatr. Res. 71:324-331.

Thomas, L. 1998. Urea and blood urea nitrogen. Pages 374-377 in Clinical Laboratory Diagnostics: Use and Assessment of Clinical Laboratory Results. 1st ed. TH-Books Verlagsgesellschaft, Frankfurt, Germany.

Van Keulen, J., and B. Young. 1977. Evaluation of acid-insoluble ash as a natural marker in ruminant digestibility studies. J. Anim. Sci. 44:282-287.

Van Soest, P. J., J. Robertson, and B. Lewis. 1991. Methods for dietary fiber, neutral detergent fiber, and nonstarch polysaccharides in relation to animal nutrition. J. Dairy Sci. 74:3583-3597.

Wattiaux, M. A., and K. L. Karg. 2004. Protein level for alfalfa and corn-silage based diets: I. Lactational response and milk urea nitrogen. J. Dairy Sci. 87:3480-3491.

Weekes, T. L., P. Luimes, and J. Cant. 2006. Responses to amino acid imbalances and deficiencies in lactating dairy cows. J. Dairy Sci. 89:2177-2187.

Weigel, D. J., J. Elliott, and J. Clark. 1997. Effects of amount and ruminal degradability of protein on nutrient digestibility and production by cows fed tallow. J. Dairy Sci. 80:1150-1159.

Wright, T. C., S. Moscardini, P. Luimes, P. Susmel, and B. McBride. 1998. Effects of rumen-undegradable protein and feed intake on nitrogen balance and milk protein production in dairy cows. J. Dairy Sci. 81:784-793.

Wu, Z., and L. D. Satter. 2000. Milk production during the complete lactation of dairy cows fed diets containing different amounts of protein. J. Dairy Sci. 83:1042-1051. 